\title{
Killing of pathogens associated with chronic granulomatous disease by the non-oxidative microbicidal mechanisms of human neutrophils
}

\author{
E.W. ODELL and A.W. SEGAL* \\ Department of Oral Medicine and Pathology, UMDS, Guy's Hospital, London Bridge, London SE1 9RT and 'Department \\ of Medicine, University College London, The Rayne Institute, University Street, London WC1E 6JJ
}

\begin{abstract}
Summary. The susceptibility of opportunist pathogens associated with chronic granulomatous disease (CGD) to the non-oxidative killing mechanisms of neutrophils has been assessed by incubation in human neutrophil primary granule lysate. The dose and pH-dependency of killing of Aspergillus fumigatus, Candida albicans, Escherichia coli, Nocardia asteroides, Serratia marcescens and Staphylococcus aureus differed markedly and may partly explain their virulence in CGD, in which oxygen-dependent killing mechanisms are defective. At the acid pH in CGD neutrophil phagosomes $S$. aureus, Ser. marcescens, $N$. asteroides and $A$. fumigatus spores were highly resistant but $C$. albicans, a less frequent pathogen in patients with CGD, was much more susceptible.
\end{abstract}

\section{Introduction}

Neutrophil polymorphonuclear leucocytes kill micro-organisms by oxygen-dependent and oxygenindependent mechanisms. In the former, oxygen is consumed in the respiratory burst to produce hydrogen peroxide and other microbicidal compounds such as hypochlorous acid and chloramines, whereas oxygenindependent killing depends on the delivery into the phagosome of pre-formed antimicrobial compounds stored in the neutrophil granules. The mechanisms of both oxygen-dependent ${ }^{1}$ and oxygen-independent killing ${ }^{2}$ have recently been reviewed.

The respiratory burst is required for optimal antimicrobial function by neutrophils. Its importance is demonstrated by chronic granulomatous disease (CGD), a group of rare conditions ${ }^{3}$ in which predisposition to severe systemic infection results from absence of the respiratory burst. ${ }^{4,5}$ Neutrophils from patients with CGD have impaired microbicidal activity and digestion in vitro but are able to kill significant numbers of bacteria. ${ }^{5-7}$ Similarly, normal neutrophils under anaerobic conditions in vitro kill some bacterial species efficiently in spite of impaired antimicrobial activity against others. ${ }^{8,9}$ This microbial killing by oxygen-independent mechanisms is thought to be of importance in inflammatory environments where oxygen tension is low.

Neutrophil microbicidal compounds that act independently of the respiratory burst include bactericidal permeability-increasing factor (BPI), ${ }^{10}$ cathepsin G (formerly known as chymotrypsin-like cationic pro-

Received 5 Jan. 1990; revised version accepted 27 June 1990. tein), ${ }^{11}$ the defensins, ${ }^{12,13}$ lactoferrin, ${ }^{14}$ and lysozyme. ${ }^{15}$ In addition to these specific compounds there are several other less well characterised compounds such as cationic proteins of mol. wt $57000,{ }^{16} 55000^{17}$ and $37000^{16}$ and some degradative enzymes with microbicidal activity. ${ }^{18,19}$ The effectiveness of these compounds in vivo depends on alkalinisation of the phagosome by the neutrophil respiratory burst. ${ }^{7,20,21}$ CGD neutrophils, without a respiratory burst, fail to kill some microbial species because they rely on non-oxidative killing which is rendered less effective by poor phagosomal $\mathrm{pH}$ control. ${ }^{7}$ As a result, patients with CGD have increased susceptibility to infection, in particular with Staphylococcus aureus, Serratia marcescens, Aspergillus spp., Salmonella typhimurium and, more rarely, Escherichia coli and Candida spp. ${ }^{22-24}$

We have attempted to explain the increased virulence of some of these pathogens in CGD by assessing their susceptibility to neutrophil granule lysate in vitro. This model of non-oxidative killing imitates the CGD neutrophil phagosome into which the granule contents are liberated by degranulation ${ }^{2}$ at low $\mathrm{pH},{ }^{7}$ independently of a respiratory burst. ${ }^{4,5}$

\section{Materials and methods}

\section{Micro-organisms}

All micro-organisms except $\boldsymbol{A}$. fumigatus were human clinical isolates kindly provided by the Departments of Medical Microbiology, University College 
Hospital and Guy's Hospital, London, where they were typed by routine microbiological techniques.

Isolates of the following micro-organisms were used: $S$. aureus (Oxford strain and one wound isolate), Ser. marcescens (two wound isolates), E.coli (two gastric isolates of smooth colonial morphology), Nocardia asteroides (two pulmonary isolates) and C. albicans (one oral and one vaginal isolate). The micro-organisms were maintained on blood-agar plates and grown to mid-exponential phase by dilution of an overnight culture 1 in 100 in fresh Nutrient Broth (Oxoid). After culture at $37^{\circ} \mathrm{C}$ with vigorous shaking, the micro-organisms were harvested and washed twice by centrifugation $(13000 \mathrm{~g}$ for $1 \mathrm{~min}$ ).

Two pulmonary isolates of $A$. fumigatus (kindly provided by Dr C. Campbell, Mycological Reference Laboratory, Central Public Health Laboratory, 61 Colindale Avenue, London) were maintained on Malt Extract Agar (Oxoid). Cultures 4-5 days old were washed with Tween $200.05 \%$ in water, and spores were harvested after sedimentation of hyphae for 30 min and filtration through filter paper (Whatman no. 1). Spores were stored at $-20^{\circ} \mathrm{C}$.

Suspensions of micro-organisms and spores in water were adjusted to known density by spectrophotometry at $600 \mathrm{~nm}$.

\section{Preparation of human neutrophils}

Normal human neutrophils were separated from buffy coat residues (National Blood Transfusion Service) by dextran sedimentation and Ficoll-Hypaque centrifugation after dilution with an equal volume of isotonic saline. Residual erythrocytes were removed by hypotonic lysis in water for $15 \mathrm{~s}$ to give a suspension containing more than $95 \%$ neutrophils. All further procedures were performed at $4^{\circ} \mathrm{C}$.

\section{Preparation of primary gramules and granule extract}

Neutrophils were suspended in sucrose $6 \% \mathrm{w} / \mathrm{v}$ and disrupted by nitrogen cavitation at $7 \times 10^{6} \mathrm{~Pa}$ after equilibration for $1 \mathrm{~h}$. A post-nuclear supernate $(230 \mathrm{~g}$ for $30 \mathrm{~min}$ ) was fractionated by sucrose density gradient centrifugation as previously described. ${ }^{25}$ Primary granules banded at a specific gravity of $1.225 \mathrm{~g} / \mathrm{ml}$ and were identified by the marker enzyme myeloperoxidase (MPO: E.C. 1.11.1.7) as measured by guaiacol peroxidation. ${ }^{26}$

Primary granules were washed three times by centrifugation $(100000 \mathrm{~g}$ for $30 \mathrm{~min})$ and extracted in $0.2 \mathrm{M}$ sodium acetate-acetic acid, $\mathrm{pH} 4 \cdot 0$, at $4^{\circ} \mathrm{C}$ for $20 \mathrm{~h}$ in a rotating tube. ${ }^{27}$ Insoluble material was removed by centrifugation ( $1430 \mathrm{~g}$ for $10 \mathrm{~min}$ followed by $100000 \mathrm{~g}$ for $30 \mathrm{~min}$ ) and the supernate was dialysed extensively against $154 \mathrm{mM} \mathrm{NaCl}$ with benzoylated dialysis membrane (mol. wt cut-off 1000; Sigma) to retain low mol. wt components. Granule extract was stored at $-20^{\circ} \mathrm{C}$ at a final concentration of $1.8 \mathrm{mg} / \mathrm{ml}$. Granule extract was subjected to sodium dodecyl sulphate-polyacrylamide gel electrophoresis (SDS-PAGE). ${ }^{28}$

To determine the identity of components of the granule extract responsible for the killing of $S$. aureus observed at alkaline $\mathrm{pH}$, the extract was fractionated into four peaks by gel filtration on Sephacryl S100. ${ }^{29}$ Granule extract $(0.5 \mathrm{ml})$ was separated on a column $300 \times 20 \mathrm{~mm}$ equilibrated with $145 \mathrm{mM} \mathrm{NaCl}$ buffered with $10 \mathrm{mM}$ phosphate buffer, $\mathrm{pH}$ 7.5. Fractions from each peak were tested for activity at $\mathrm{pH} 7 \cdot 5$. Protein assays were performed with the Pierce BCA system (Pierce, Rockford, IL, USA).

\section{Killing assays}

Killing assays were performed as previously described. ${ }^{30}$ Micro-organisms were suspended at a final concentration of $10^{6} \mathrm{cfu} / \mathrm{ml}$ in $10 \mathrm{mM}$ citrate phosphate buffer, pH 7, ${ }^{31}$ with $1 \mathrm{mM} \mathrm{CaCl}_{2}, 1 \mathrm{mM} \mathrm{MgCl}, 5 \mathrm{mM}$ glucose and $113 \mathrm{mM} \mathrm{NaCl}$ supplemented with neutrophil primary granule extract at various concentrations. Fractions of granule extract were tested against microorganisms adjusted to a final concentration of $10^{5} \mathrm{cfu} /$ $\mathrm{ml}$ with bovine serum albumin $0.2 \mathrm{mg} / \mathrm{ml}$. The reaction volume was usually $500 \mu \mathrm{l}$, but some assays were performed in $50 \mu$ l. To investigate the $\mathrm{pH}$ dependency of killing, the buffer was adjusted to $\mathrm{pH}$ values from 5.5 to 8.0 . Suspensions were incubated, with mixing, at $37^{\circ} \mathrm{C}$ for $60 \mathrm{~min}$ and surviving micro-organisms were counted by serial dilution and colony counting on suitable media by routine methods. ${ }^{32}$ Results were calculated as the mean and SEM from at least three experiments with colony counts performed in triplicate or quadruplicate for each sample and expressed as a percentage of the original viability, as determined by control assays performed in buffer alone. The $\mathrm{pH}$ remained stable during assays to within $0.15 \mathrm{pH}$ units of the starting $\mathrm{pH}$. Statistical comparisons were made with Student's $t$ test.

\section{Results}

Extracted proteins were representative of whole granules, as judged by SDS-PAGE (data not shown), reflecting the high efficiency of this extraction procedure. ${ }^{33}$ Granule extract showed antimicrobial activity against some species with the potency highly dependent on the assay conditions. The dose dependency of killing at $\mathrm{pH} 7.0$ is shown in fig. 1 . Different microorganisms showed different susceptibility to granule extracts. S. aureus and E. coli showed a threshold effect, a significant reduction of viability occurring over a small dose range. The killing of $C$. albicans was directly proportional to dose over a much wider dose range. A.fumigatus spores, Ser. marcescens and $N$. asteroides were highly resistant to granule extract.

The $\mathrm{pH}$ dependency of killing for each strain is shown in fig. 2. E. coli and C.albicans were more 
a
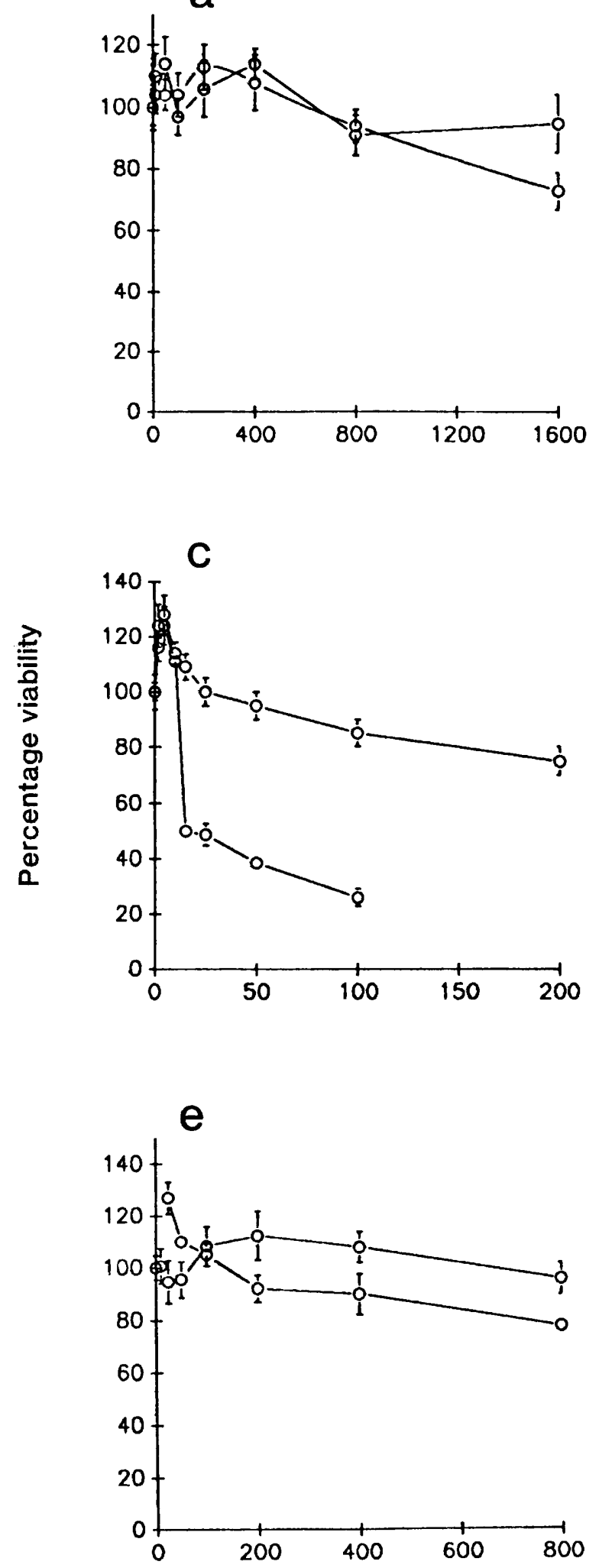

b
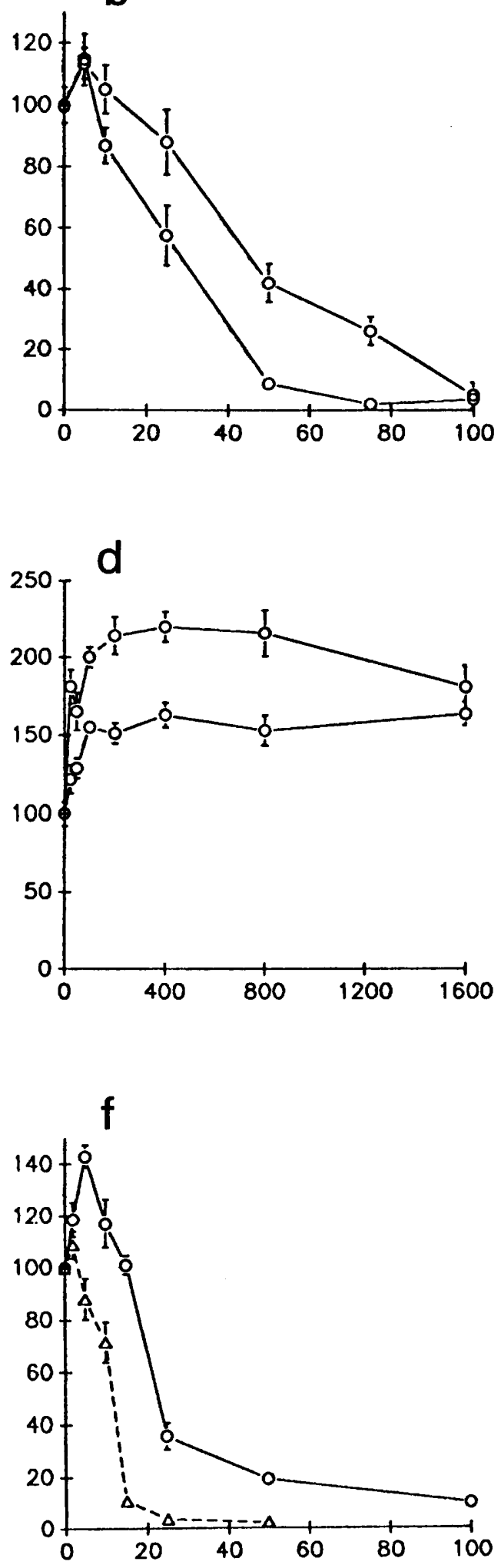

\section{Granule extract $(\mu \mathrm{g} / \mathrm{ml})$}

Fig. 1. Each graph shows the killing of two strains of each micro-organism $\left(10^{6} \mathrm{cfu} / \mathrm{ml}\right)$ exposed to various doses of granule extract at $37^{\circ} \mathrm{C}$ for $60 \mathrm{~min}$ at $\mathrm{pH} \mathrm{7.0.} \mathrm{The} \mathrm{mean} \mathrm{and} \mathrm{SEM} \mathrm{of} \mathrm{three} \mathrm{experiments} \mathrm{is} \mathrm{shown.} \mathrm{Colony} \mathrm{counts} \mathrm{were} \mathrm{performed} \mathrm{in} \mathrm{quadruplicate.} \mathrm{Changes} \mathrm{in}$ viability greater than $50 \%$ were always significant (p $\leq 0.05)$. (a) A. fumigatus; (b) C. albicans; (c) E. coli; (d) N. asteroides; (e) Ser. marcescens; (f) $S$. aureus (--, Oxford strain). 
a

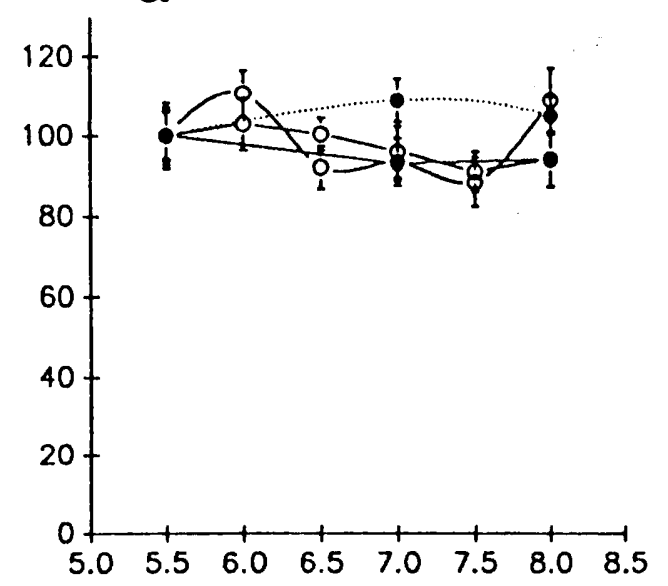

C

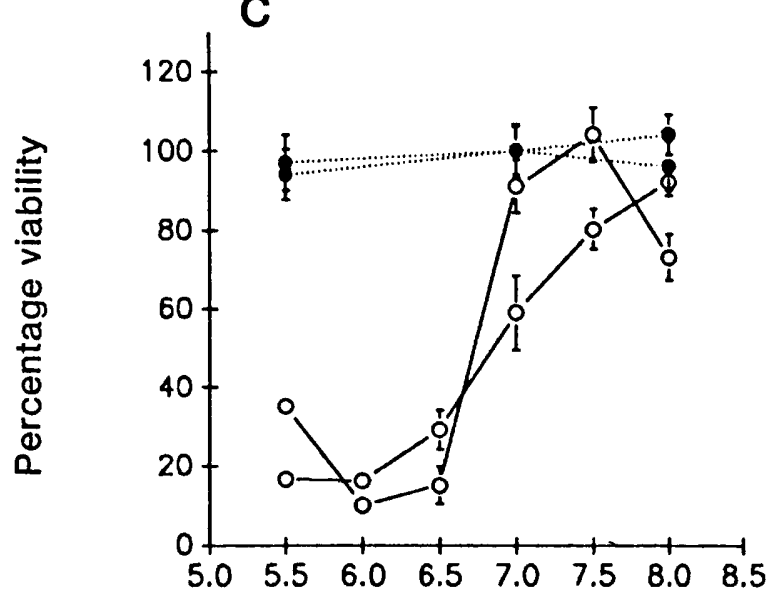

e

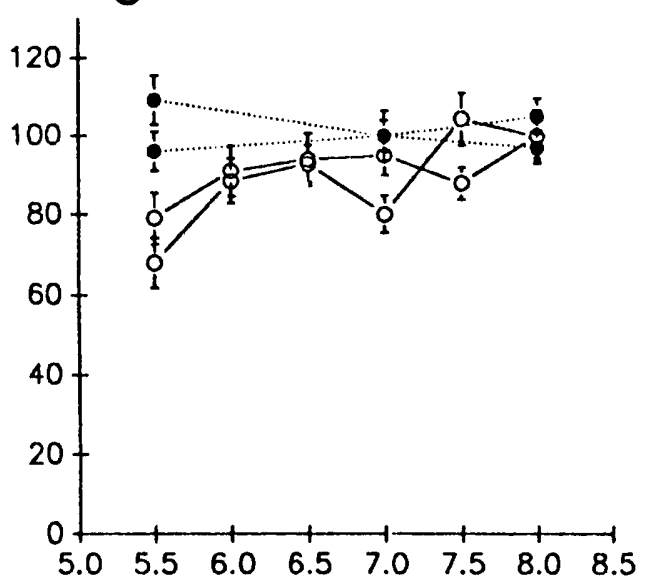

b

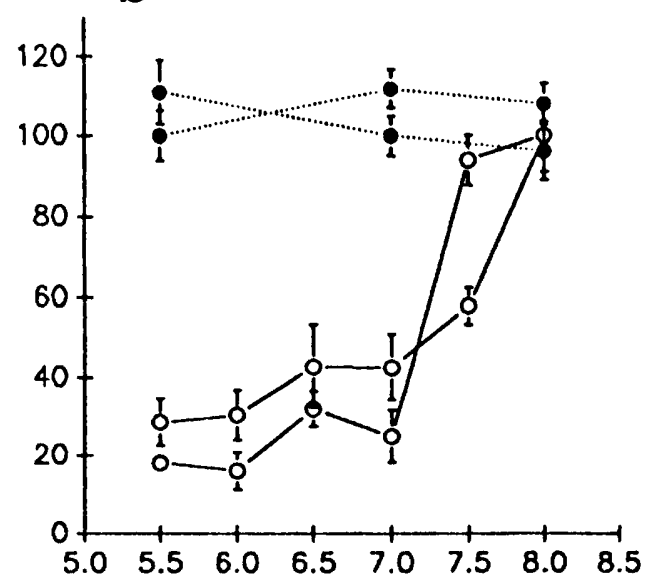

d

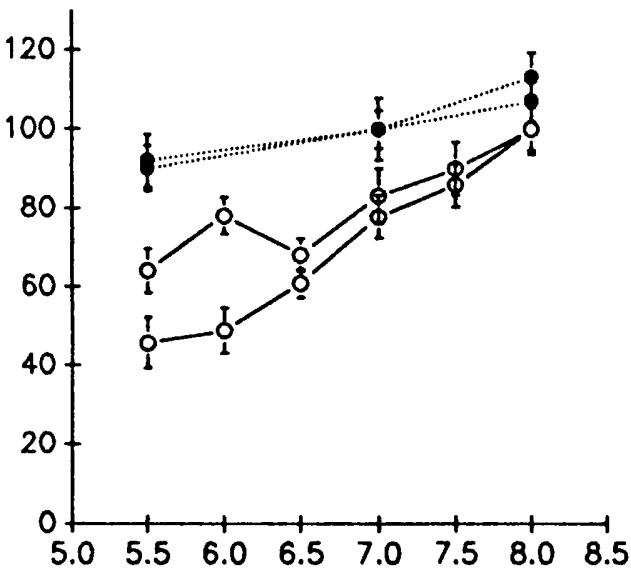

f

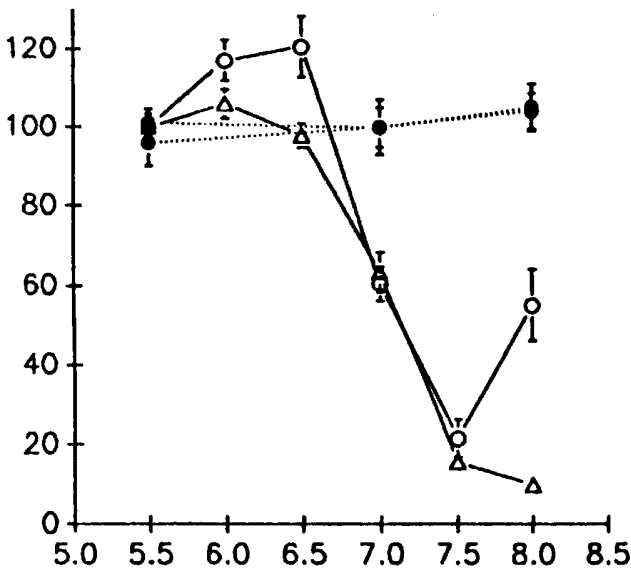

$\mathrm{pH}$

Fig. 2. Each graph shows the effect of $\mathrm{pH}$ on the killing of two strains of each micro-organism $\left(10^{6} \mathrm{cfu} / \mathrm{ml}\right)$ by the following fixed doses of granule extract at $37^{\circ} \mathrm{C}$ for $60 \mathrm{~min}(\mathrm{O}-\mathrm{O})$ : (a) A. fumigatus $(800 \mu \mathrm{g} / \mathrm{ml})$, (b) C. albicans $(50 \mu \mathrm{g} / \mathrm{ml})$, (c) $E$. coli (20 $\left.\mu \mathrm{g} / \mathrm{ml}\right)$, (d) $N$. asteroides $(400 \mu \mathrm{g} / \mathrm{ml})$, (e) Ser. marcescens $(400 \mu \mathrm{g} / \mathrm{ml})$, (f) $S$. aureus (fresh isolate $25 \mu \mathrm{g} / \mathrm{ml}$; Oxford strain $15 \mu \mathrm{g} / \mathrm{ml}$ ); $\cdots . .$. the effect of buffer alone. The mean and SEM of three experiments is shown. Colony counts were performed in quadruplicate. Changes in viability greater than $50 \%$ are significant $(\mathrm{p} \leq 0.05)$. 
susceptible to granule extract at acid $\mathrm{pH}$, whereas strains of $S$. aureus were resistant to extract at acid pH and susceptible only at neutral and alkaline pH. Ser. marcescens was very slightly more susceptible at acid $\mathrm{pH}$. $N$. asteroides was susceptible only at acid $\mathrm{pH}$, and then only at very high concentrations of extract. A. fumigatus spores were resistant at each $\mathrm{pH}$ value tested.

The bactericidal effects of extract fractions against S. aureus at alkaline $\mathrm{pH}$ are shown in fig. 3 .

\section{Discussion}

In normal neutrophils, micro-organisms are killed by the combined action of oxygen-dependent and oxygen-independent mechanisms. CGD neutrophils possess only oxygen-independent mechanisms and killing depends on the microbicidal effect of the neutrophil granule proteins. An attempt was made to correlate resistance to neutrophil granule proteins with the virulence of some of the opportunist pathogens associated with CGD.

It is not easy to associate specific pathogens with CGD by comparing frequency of infection with the normal population, because the number of cases is small and the clinical course variable. S. aureus and Ser. marcescens are isolated frequently and are particularly troublesome. ${ }^{22,23}$ Other pathogens reported include Klebsiella spp., Pseudomonas aeruginosa, S. albus, Aspergillus spp., N. asteroides, E. coli and Salmonella spp. but increased virulence cannot be inferred without further evidence of the unusual sites and severity of infection seen in CGD. The suscepti-

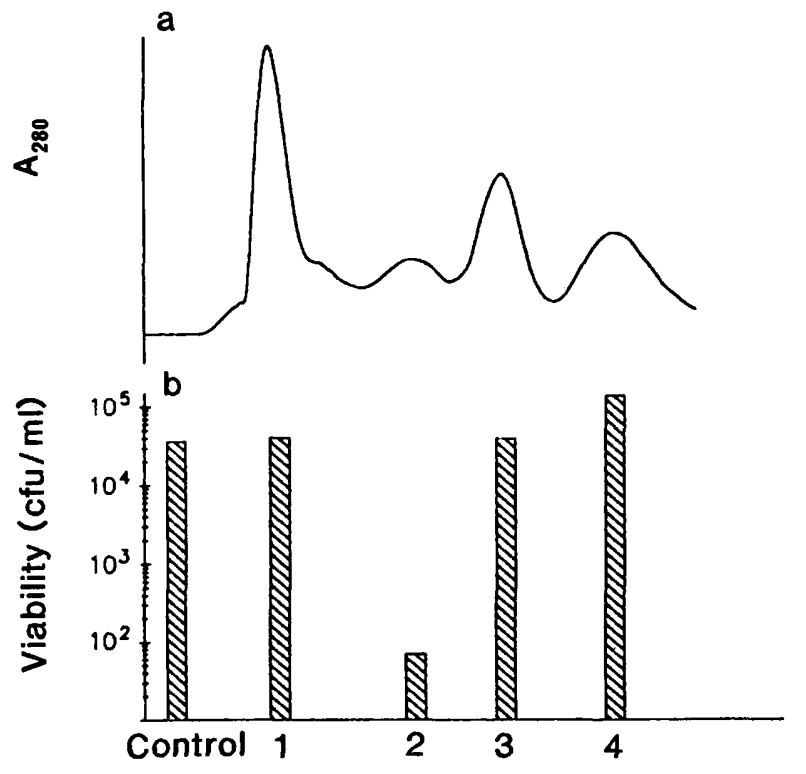

Fraction (peak no.)

Fig. 3. (a) Separation of granule extract into four peaks by gel filtration on Sephacryl S100. (b) Killing of $S$. aureus Oxford strain by fractions from each peak. The means of four experiments are shown. Colony counts were performed in quadruplicate. Final concentrations of protein incubated with $10^{5} \mathrm{cfu} / \mathrm{ml}$ were: peak 1 , $173 \mu \mathrm{g} / \mathrm{ml}$; peak 2, $85 \mu \mathrm{g} / \mathrm{ml}$; peak 3, $103 \mu \mathrm{g} / \mathrm{ml}$; peak 4, $90 \mu \mathrm{g} / \mathrm{ml}$. bility of six micro-organisms whose pathogenicity is enhanced in CGD was tested-A. fumigatus spores, clinical isolates of $N$.asteroides, S. aureus, and Ser. marcescens, and the S.aureus Oxford strain which CGD neutrophils kill in vitro with reduced efficiency. C. albicans blastospores and E. coli were also tested because, although they are not normally associated with CGD, oxygen-dependent mechanisms may be required for normal neutrophils to kill then.

Extraction of neutrophil primary granules in acetate solubilises granule components efficiently ${ }^{33}$ and the extract used was potently antimicrobial when tested against some of these micro-organisms, the pattern reflecting their virulence in CGD. Each organism shows an apparent increase in viability at some doses. This is a non-specific protein effect caused by the highly charged granule proteins binding to the microorganism surface which alters the degree of bacterial clumping and adsorption to the assay tube wall.

Optimal killing of $S$. aureus by non-oxidative mechanisms is known to require the respiratory burst. ${ }^{7,34}$ Both strains of $S$. aureus tested were susceptible to granule extract only at neutral or alkaline $\mathrm{pH}$. This neutral $\mathrm{pH}$ optimum for killing has been noted by others ${ }^{30}$ and may explain the pathogenicity of $S$. aureus, both in $\mathrm{CGD}^{7}$ and at foci of anaerobic infection. ${ }^{35}$ S. aureus is killed at acid $\mathrm{pH}$ only in the presence of a respiratory burst because the MPO system has an acid $\mathrm{pH}$ optimum. ${ }^{36}$ Fractionation of the granule extract by gel filtration showed that almost all the activity against $S$. aureus at $\mathrm{pH} 7.5$ was retrieved in peak 2. The major components of peak 2 are the neutral proteases elastase and cathepsin $\mathrm{G}^{37}$ but small amounts of BPI, the $37000-\mathrm{mol}$. wt cationic protein and other unknown factors are probably also present. Further studies will be necessary to determine the individual components responsible for the killing.

Ser. marcescens, $N$. asteroides and $A$. fumigatus were markedly resistant to granule extract. Protection against Ser. marcescens is mediated in part by neutrophils ${ }^{38}$ and Ser. marcescens is a frequent pathogen in CGD. Its killing of Ser. marcescens is delayed in MPO-deficient neutrophils ${ }^{39}$ and impaired in CGD neutrophils, ${ }^{34}$ which points to the importance of the MPO system. The strains used in the current investigation were highly resistant to granule extract at every $\mathrm{pH}$ value tested and this may explain the pathogenicity of this species in CGD, where MPO and oxygen-dependent killing systems are defective.

$N$. asteroides is also associated with infection in CGD and is highly resistant to killing by neutrophils and monocytes, ${ }^{40}$ although neutrophils can exert a bacteriostatic effect by preventing filament formation. ${ }^{41}$ This effect is oxygen-independent and is normally exerted by CGD neutrophils and by granule extract in vitro..$^{41}$ Resistance to killing may also be due partly to inhibition of degranulation ${ }^{42}$ and of acidification. ${ }^{43}$ In these studies, $N$. asteroides was found to be extremely resistant to killing by granule extract but the techniques used in the present study do not detect 
the bacteriostatic effects previously reported. ${ }^{41}$ Thus, although other mechanisms may confer pathogenicity on $N$.asteroides it is clearly resistant to neutrophil non-oxidative killing.

A. fumigatus and C. albicans are opportunist pathogens and, therefore, likely to be susceptible to killing by neutrophils. ${ }^{44}$ The susceptibility of Aspergillus spp. to killing by neutrophils depends on the stage of the life cycle. Conidia stimulate neutrophils poorly and are highly resistant to oxidative ${ }^{45}$ and non-oxidative ${ }^{46}$ killing mechanisms. They are more easily killed by resident macrophages from some sites, ${ }^{47}$ or during growth phases..$^{45,46}$ The hyphal form is more easily killed by neutrophils, ${ }^{48}$ and rabbit $^{46}$ and human ${ }^{49}$ neutrophil granule lysates are also effective, though slightly less efficient. Neutrophils from patients with CGD or MPO deficiency are less able to damage hyphal forms than normal neutrophils. ${ }^{49}$ In the present investigation, $\boldsymbol{A}$. fumigatus spores were shown to be highly resistant to granule extract, thus confirming previous results. ${ }^{46}$ However, it is unclear whether the resistance of the spores might be important in initiating infection in patients with CGD. Survival of A. fumigatus spores in vitro may be further aided by uncharacterised diffusible factors which have been reported to inhibit neutrophil function. ${ }^{50}$

The killing of Candida spp. by human neutrophils has been reported to depend on both MPO and the respiratory burst, as judged by CGD neutrophils, anaerobic culture ${ }^{51}$ and MPO deficiency. ${ }^{39,52}$ However, Candida spp. are susceptible to non-oxidative killing by cathepsin G, defensins and lysozyme. The killing of $C$. albicans reported here was directly doserelated over a wide range of doses, as previously reported. ${ }^{53}$ C. albicans was killed best at low $\mathrm{pH}$, which suggests that defensins alone do not mediate the effect. ${ }^{54}$ This $\mathrm{pH}$ dependency may explain why these micro-organisms are not common pathogens in CGD, because they would be killed by granule components in the more acid phagosome.

$E$. coli is reported to cause frequent systemic infections in CGD. ${ }^{22,23}$ There are marked differences in the susceptibility to non-oxidative killing within the species, reflecting the potency and target specificity of BPI. ${ }^{10}$ E. coli can be susceptible to BPI, defensins, and the $57000-$ and $37000-\mathrm{mol}$. wt cationic antimicrobial proteins and, to a lesser degree, lysozyme, although smooth strains are generally resistant to BPI. ${ }^{55}$ In view of the known potency of BPI towards $E$. coli, it would be expected that smooth strains would be more pathogenic in CGD, but such a distinction between strains is not made in reported studies. The strains of $E$. coli used in these experiments showed marked variation in susceptibility to granule extract, although the effect of $\mathrm{pH}$ was similar for both. Since killing by crude lysate is optimal at acid $\mathrm{pH}$ rather than at neutrality, it is unlikely that BPI is responsible for the observed killing.

The pathogenicity of micro-organisms is multifactorial and depends on their ability to evade all the host defence systems in vivo, not just the neutrophil nonoxidative mechanisms. However, the results of these investigations suggest that the susceptibility and $\mathrm{pH}$ dependence of granule-extract mediated killing may help explain microbial virulence in CGD where killing depends on non-oxidative mechanisms alone. $S$. aureus clearly requires neutral $\mathrm{pH}$ for effective nonoxidative killing and is resistant at the acid $\mathrm{pH}$ found in the phagosomes of CGD neutrophils. This finding lends support to the suggestion that an important function of the respiratory burst is to control phagosomal $\mathrm{pH}$. Species such as Ser. marcescens, $N$. asteroides and $\boldsymbol{A}$. fumigatus are highly resistant to granule extract over a wide $\mathrm{pH}$ range and would be resistant to killing in CGD neutrophils. These species are presumably killed efficiently by oxidative mechanisms in normal neutrophils as they are uncommon pathogens in the normal population. C. albicans may be an uncommon pathogen in CGD because it is susceptible to non-oxidative killing at the acid $\mathrm{pH}$ found in the CGD neutrophil phagosome.

We are grateful to the staff of the South London Blood Transfusion Centre for providing buffy coat residues and Dr C. Campbell, Mycological Reference Laboratory, CPHLS, for providing strains of A. fumigatus. We thank the Medical Research Council, The Wellcome Trust and the Special Trustees of University College Hospital for financial support.

\section{References}

1. Klebanoff SJ. Phagocytic cells : products of oxygen metabolism. In: Gallin JI, Goldstein IM, Snyderman R (eds) Inflammation: basic principles and clinical correlates. New York, Raven Press. 1988:391-444.

2. Elsbach P, Weiss J. Phagocytic cells: oxygen-independent antimicrobial systems. In: Gallin JI, Goldstein IM, Snyderman $\mathbf{R}$ (eds) Inflammation: basic principles and clinical correlates. New York, Raven Press: 1988:445-470.

3. Segal AW. The electron transport chain of the microbicidal oxidase of phagocytic cells and its involvement in the molecular pathology of chronic granulomatous disease. $J$ Clin Invest 1989; 83:1785-1793.

4. Holmes B, Page AR, Good RA. Studies of the metabolic activity of leukocytes from patients with a genetic abnormality of phagocytic function. $J$ Clin Invest 1967; 46: $1422-1432$.

5. Quie PG, White JG, Holmes B, Good RA. In vitro bactericidal capacity of human polymorphonuclear leukocytes : diminished activity in chronic granulomatous disease of childhood. J Clin Invest 1967; 46:668-679.

6. Rest RF, Fischer SH, Ingham ZZ, Jones JF. Interactions of Neisseria gonorrhoeae with human neutrophils: effects of serum and gonococcal opacity on phagocyte killing and chemiluminescence. Infect Immun 1982; 36:737-744.

7. Segal AW, Geisow M, Garcia R, Harper A, Miller R. The respiratory burst of phagocytic cells is associated with a rise in vacuolar pH. Nature $1981 ; 290: 406-409$.

8. Mandell GL. Bactericidal activity of aerobic and anaerobic polymorphonuclear neutrophils. Infect Immun 1974; 9:337341.

9. Okamura N, Spitznagel JK. Outer membrane mutants of Salmonella typhimurium LT2 have lipopolysaccharidedependent resistance to the bactericidal activity of anaerobic human neutrophils. Infect Immun 1982; 36:10861095.

10. Weiss J, Elsbach P, Olsson I, Odeberg H. Purification and 
characterization of a potent bactericidal and membraneactive protein from the granules of human polymorphonuclear leucocytes. J Biol Chem 1978; 253: 2664-2672.

11. Odeberg H, Olsson I. Mechanisms for the microbicidal activity of cationic proteins of human granulocytes. Infect Immun $1976 ; 14: 1269-1275$.

12. Selsted ME, Brown DM, DeLange RJ, Harwig SSL, Lehrer RI. Primary structures of six antimicrobial peptides of rabbit peritoneal neutrophils. J Biol Chem 1985; 260:4579-4584.

13. Ganz T, Selsted ME, Szklarek D et al. Defensins. Natural peptide antibiotics of human neutrophils. $J$ Clin Invest $1985 ; 76: 1427-1435$.

14. Arnold RR, Russell JE, Champion WJ, Brewer M, Gauthier JJ. Bactericidal activity of human lactoferrin: differentiation from the stasis of iron deprivation. Infect Immun 1982; 35: $792-799$.

15. Iacono VJ, MacKay B, DiRienzo S, Pollock JJ. Selective antibacterial properties of lysozyme for oral micro-organisms. Infect Immun 1980; 29:623-632.

16. Shafer WM, Martin LE, Spitznagel JK. Cationic antimicrobial proteins isolated from human neutrophil granulocytes in the presence of diisopropyl fluorophosphate. Infect Immun $1984 ; 45: 29-35$.

17. Hovde CJ, Gray BH. Physiological effects of a bactericidal protein from human polymorphonuclear leukocytes on Pseudomonas aeruginosa. Infect Immun 1986; 52:90-95.

18. Janoff A, Blondin J. The effect of human granulocyte elastase on bacterial suspensions. Lab Invest 1973; 29:454-457.

19. Thorne KJI, Oliver RC, Barrett AJ. Lysis and killing of bacteria by lysosomal proteinases. Infect Immun 1976; 14:555-563.

20. Cech P, Lehrer RI. Phagolysosomal pH of human neutrophils. Blood 1984; 63:88-95.

21. Mayer SJ, Keen PM, Craven N, Bourne FJ. Regulation of phagolysosome $\mathrm{pH}$ in bovine and human neutrophils: the role of NADPH oxidase activity and an $\mathrm{Na}^{+} / \mathrm{H}^{+}$antiporter. J Leukoc Biol 1989; 45: 239-248.

22. Johnston RB, Newman SL. Chronic granulomatous disease. Pediatr Clin North Am 1977; 24:365-76.

23. Donowitz GR, Mandell GL. Clinical presentation and unusual infections in chronic granulomatous disease. In: Gallin JI, Fauci AS (eds) Advances in host defence mechanisms, vol 3; Chronic granulomatous disease. New York, Raven Press. 1983:55-75.

24. Mouy R, Fischer A, Vilmer E, Seger R, Griscelli C. Incidence, severity, and prevention of infections in chronic granulomatous disease. J Pediatr 1989; 114:555-560.

25. Segal AW, Garcia RC, Harper AM, Banga JP. Iodination by stimulated human neutrophils. Biochem J 1983; 210:215225.

26. Chance B, Maehly AC. Assay of catalases and peroxidases. Methods Enzymol 1955; 2:764-775.

27. Rest RF, Cooney MH, Spitznagel JK. Susceptibility of lipopolysaccharide mutants to the bactericidal action of human neutrophil lysosomal fractions. Infect Immun 1977; 16: 145-151.

28. Laemmli UK. Cleavage of structural proteins during the assembly of the head of bacteriophage T4. Nature 1970; 227:680-685.

29. Modrzakowski MC, Paranavitana CM. Bactericidal activity of fractionated granule contents from human polymorphonuclear leukocytes: role of bacterial membrane lipid. Infect Immun $1981 ; 32: 668-674$.

30. Craven N, Williams MR, Field TR, Bunch KJ, Mayer SJ, Bourne FJ. The influence of extracellular and phagolysosomal $\mathrm{pH}$ changes on the bactericidal activity of bovine neutrophils against Staphylococcus aureus. Vet Immunol Immunopathol 1986; 13:97-110.

31. McIlvaine TC. A buffer solution for colorimetric comparison. $J$ Biol Chem 1921 ; 49:183-186.

32. Meynell GG, Meynell E. Bacterial growth. In: Meynell GG, Meynell $E$ (eds) Theory and practice in experimental bacteriology. Cambridge, Cambridge University Press. 1970:1-34.

33. Weiss J, Olsson I. Cellular and subcellular localization of the bactericidal/permeability-increasing protein of neutrophils. Blood 1987; 69: 652-659.

34. Dilworth JA, Mandell GL. Adults with chronic granulomatous disease of "childhood". Am J Med 1977; 63:233-243.
35. Mayer SJ, Craven N, Keen PM, Bourne FJ. Effect of pH changes on the killing of Staphylococcus aureus and other mastitis pathogens by bovine neutrophil granule extracts. Res Vet Sci 1988; 44:324-328.

36. Styrt B, K lempner MS. Effects of pH on killing of Staphylococcus aureus and Escherichia coli by constituents of the neutrophil phagolysosome. J Med Microbiol 1988; 25:101-107.

37. Rindler-Ludwig R, Schmalzl F, Braunsteiner, $\mathbf{H}$. Esterases in human neutrophil granulocytes: evidence for their protease nature. Br J Haematol 1974; 27:57-64.

38. Okada K. Analysis of protective mechanisms against infection by Serratia marcescens. J Clin Lab Immunol 1985; 16:183190.

39. Lehrer RI, Hanifin J, Cline MJ. Defective bactericidal activity in myeloperoxidase-deficient neutrophils. Nature 1969; 223: 78-79.

40. Filice GA, Beaman BL, Krick JA, Remington JS. Effects of human neutrophils and monocytes on Nocardia asteroides: failure of killing despite occurrence of the oxidative metabolic burst. J Infect Dis 1980; 142:432-438.

41. Filice GA. Inhibition of Nocardia asteroides by neutrophils. $J$ Infect Dis 1985; $151: 47-56$.

42. Davis-Scibienski CD, Beaman BL. Interaction of Nocardia asteroides with rabbit alveolar macrophages: association of virulence, viability, ultrastructural damage, and phagosome-lysosome fusion. Infect Immun 1980; 28:610-619.

43. Black CM, Paliescheskey M, Beaman BL, Donovan RM, Goldstein E. Acidification of phagosomes in murine macrophages: blockage by Norcardia asteroides. J Infect Dis 1986; 154:952-958.

44. Schaffner A, Davis CE, Schaffner T, Markert M, Douglas $H$, Braude AI. In vitro susceptibility of fungi to killing by neutrophil granulocytes discriminates between primary pathogenicity and opportunism. JClin Invest 1986; 78:511524.

45. Levitz SM, Diamond RD. Mechanisms of resistance of Aspergillus fumigatus conidia to killing by neutrophils in vitro. J Infect Dis 1985; 152:33-42.

46. Levitz SM, Selsted ME, Ganz T, Lehrer RI, Diamond RD. In vitro killing of spores and hyphae of Aspergillus fumigatus and Rhizopus oryzae by rabbit neutrophil cationic peptides and bronchoalveolar macrophages. J Infect Dis 1986; 154:483-489.

47. Schaffner A, Douglas H, Braude AI, Davis CE. Killing of Aspergillus spores depends on the anatomical source of the macrophage. Infect Immun 1983; 42:1109-1115.

48. Schaffner A, Douglas H, Braude A. Selective protection against conidia by mononuclear and against mycelia by polymorphonuclear phagocytes in resistance to Aspergillus. Observations on these two lines of defence in vivo and in vitro with human and mouse phagocytes. J Clin Invest 1982; 69:617-631.

49. Diamond RD, Clark RA. Damage to Aspergillus fumigatus and Rhizopus oryzae hyphae by oxidative and nonoxidative microbicidal products of human neutrophils in vitro. Infect Immun 1982; 38:487-495.

50. Robertson MD, Seaton A, Raeburn JA, Milne LJR. Inhibition of phagocyte migration and spreading by spore diffusates of Aspergillus fumigatus. J Med Vet Mycol 1987; 25:389396.

51. Lehrer RI, Cline MJ. Interaction of Candida albicans with human leukocytes and serum. $J$ Bacteriol 1969 ; 98 :9961004.

52. Klebanoff SJ. Myeloperoxidase: Contribution to the microbicidal activity of intact leukocytes. Science 1970; 169 : 10951097.

53. Drazin RE, Lehrer RI. Fungicidal properties of a chymotrypsinlike cationic protein from human neutrophils: adsorption to Candida parapsilosis. Infect Immun 1977; 17:382-388.

54. Selsted ME, Szklarek D, Ganz T, Lehrer RI. Activity of rabbit leukocyte peptides against Candida albicans. Infect Immun 1985; 49:202-206.

55. Weiss J, Beckerdite-Quagliata S, Elsbach P. Resistance of gram-negative bacteria to purified bactericidal leukocyte proteins. Relation to binding and bacterial lipopolysaccharide structure. J Clin Invest 1980; 65:619-628. 
